\title{
Exercise training restores uncoupling protein-3 content in limb muscles of patients with chronic obstructive pulmonary disease
}

Citation for published version (APA):

Gosker, H. R., Schrauwen, P., Broekhuizen, R., Hesselink, M. K., Moonen Kornips, E., Ward, K. A., Franssen, F. M., Wouters, E. F., \& Schols, A. M. (2006). Exercise training restores uncoupling protein-3 content in limb muscles of patients with chronic obstructive pulmonary disease. American Journal of Physiology : Endocrinology and Metabolism, 290(5), E976-E981.

https://doi.org/10.1152/ajpendo.00336.2005

Document status and date:

Published: 01/01/2006

DOI:

10.1152/ajpendo.00336.2005

Document Version:

Publisher's PDF, also known as Version of record

\section{Document license:}

Taverne

Please check the document version of this publication:

- A submitted manuscript is the version of the article upon submission and before peer-review. There can be important differences between the submitted version and the official published version of record.

People interested in the research are advised to contact the author for the final version of the publication, or visit the DOI to the publisher's website.

- The final author version and the galley proof are versions of the publication after peer review.

- The final published version features the final layout of the paper including the volume, issue and page numbers.

Link to publication

\footnotetext{
General rights rights.

- You may freely distribute the URL identifying the publication in the public portal. please follow below link for the End User Agreement:

www.umlib.nl/taverne-license

Take down policy

If you believe that this document breaches copyright please contact us at:

repository@maastrichtuniversity.nl

providing details and we will investigate your claim.
}

Copyright and moral rights for the publications made accessible in the public portal are retained by the authors and/or other copyright owners and it is a condition of accessing publications that users recognise and abide by the legal requirements associated with these

- Users may download and print one copy of any publication from the public portal for the purpose of private study or research.

- You may not further distribute the material or use it for any profit-making activity or commercial gain

If the publication is distributed under the terms of Article 25fa of the Dutch Copyright Act, indicated by the "Taverne" license above, 


\title{
Exercise training restores uncoupling protein-3 content in limb muscles of patients with chronic obstructive pulmonary disease
}

\author{
Harry R. Gosker, ${ }^{1}$ Patrick Schrauwen, ${ }^{2}$ Roelinka Broekhuizen, ${ }^{1}$ Matthijs K. C. Hesselink, ${ }^{3}$ \\ Esther Moonen-Kornips, ${ }^{2}$ Kimberly A. Ward, ${ }^{1}$ Frits M. E. Franssen, ${ }^{1}$ \\ Emiel F. M. Wouters, ${ }^{1}$ and Annemie M. W. J. Schols ${ }^{1}$ \\ Departments of ${ }^{1}$ Respiratory Medicine, ${ }^{2}$ Human Biology, and ${ }^{3}$ Movement Sciences, Nutrition \\ and Toxicology Research Institute Maastricht, Maastricht University, Maastricht, The Netherlands
}

Submitted 25 July 2005; accepted in final form 9 December 2005

Gosker, Harry R., Patrick Schrauwen, Roelinka Broekhuizen, Matthijs K. C. Hesselink, Esther Moonen-Kornips, Kimberly A. Ward, Frits M. E. Franssen, Emiel F. M. Wouters, and Annemie M. W. J. Schols. Exercise training restores uncoupling protein-3 content in limb muscles of patients with chronic obstructive pulmonary disease. Am J Physiol Endocrinol Metab 290: E976-E981, 2006. First published December 13, 2005; doi:10.1152/ajpendo.00336.2005.-Oxidative capacity and uncoupling protein-3 (UCP3) content are reduced in limb muscles of patients with chronic obstructive pulmonary disease (COPD). It has been hypothesized that the physiological role of UCP3 is to protect mitochondria against lipotoxicity in cases where fatty acid influx exceeds the capacity to oxidize them. Exercise training improves oxidative capacity and reduces UCP3 protein content in healthy subjects, but the response of UCP3 to training in COPD is unknown. We studied the effect of exercise training on UCP3 content in limb muscles of COPD patients. For this, seven healthy age-matched subjects and thirteen patients with COPD were studied. All patients were admitted to an 8-wk exercise training intervention. Exercise capacity was assessed by means of an incremental cycle ergometry test. Biopsies were taken from the vastus lateralis in which UCP3 and lipid peroxidation levels were determined by Western blotting. Citrate synthase and 3-hydroxyacyl-CoA dehydrogenase (HAD; an enzyme involved in fatty acid oxidation) were measured as indexes of muscle oxidative capacity. UCP3 in COPD was $\sim 50 \%$ lower compared with healthy age-matched controls. In COPD, training induced upregulation of UCP3 [from 67.7 (SD 41.8) to 113.8 (SD 104.2) arbitrary units (AU), $P=0.062$ ], especially in the patients who showed no increase in HAD activity [from 80.9 (SD 52.6) to 167.9 (SD 109.1) AU, $P=0.028$, whereas lipid peroxidation levels remained unaltered. We conclude that exercise-training can restore muscle UCP3 protein level in COPD, and the nature of this response complies with the hypothesis that UCP3 may protect against lipotoxicity.

skeletal muscle; obstructive lung diseases; exercise therapy; 3-hydroxyacyl-coenzyme A dehydrogenases; mitochondrial uncoupling protein-3

EVIDENCE IS ACCUMULATING THAT peripheral skeletal muscle impairment significantly contributes to exercise intolerance in patients with chronic obstructive pulmonary disease (COPD). This muscular dysfunction is reflected by reduced muscle strength, endurance, and mechanical efficiency $(11,12,23)$. Intrinsic abnormalities have been described in COPD that are potentially involved in muscle dysfunction. Reduced fiber type I proportions and a I-to-IIX fiber-type shift have been shown $(14,19,26)$. In addition, in line with this fiber type redistribution, decreased activities of enzymes involved in oxidative

\footnotetext{
Address for reprint requests and other correspondence: H. R. Gosker, Dept of Respiratory Medicine, Maastricht Univ., Nutrition and Toxicology Research Institute Maastricht, P.O. Box 616, 6200 MD Maastricht, The Netherlands (e-mail: H.Gosker@pul.unimaas.nl).
}

metabolism have been reported $(20,25)$. Given a potential role for uncoupling protein-3 (UCP3) in human substrate metabolism (32) and given the fiber-type-specific expression of UCP3, with higher levels in type II fibers (16), we have recently examined UCP3 levels in muscle biopsies from COPD patients and healthy control subjects. In contrast to what could be expected from fiber-type distribution, we and others found reduced UCP3 content in COPD instead $(13,30)$. At present, the exact physiological function of UCP3 is not known, but there is compelling evidence that UCP3 is involved in the mitochondrial fatty acid anion export (34). In situations where fatty acid supply to mitochondria exceeds the oxidizing capacity, fatty acids will accumulate in the matrix where they become deprotonated and can subsequently become peroxidized. UCP3 is suggested to be involved in clearing the matrix from these fatty acid anions (36), thereby protecting the mitochondria against lipid peroxide-induced damage (lipotoxicity). Interestingly, increased levels of intramuscular lipid peroxidation products have indeed been reported for COPD $(2,8)$. In addition, recent data suggest that the low muscle UCP3 levels in COPD may be linked to disturbed fatty acid metabolism (30).

In accordance with this putative function of UCP3, exercise training improves fat oxidative capacity and therefore allows UCP3 levels to decrease in healthy subjects (31). In COPD patients, exercise training has proven to be beneficial despite severe ventilatory impairment. Some studies showed that improvement in exercise capacity is accompanied by partly restored muscular activities of the oxidative enzymes citrate synthase (CS) and 3-hydroxyacyl-CoA dehydrogenase (HAD; see Refs. 24 and 28), which is a normal physiological response to endurance training. HAD is an important enzyme involved in the oxidation of fatty acids and therefore of particular interest with respect to UCP3. Because UCP3 is already low in COPD, the question remains whether endurance training in COPD will further reduce UCP3 levels. We therefore examined the effect of an 8-wk supervised exercise training intervention on muscular UCP3 levels in this disease. In addition, we monitored changes in lipid peroxidation and in metabolic profile by activity measurements of glycolytic enzymes and oxidative enzymes, including HAD, as well as myosin heavy chain (MyHC) isoform composition, which reflects fiber type distribution.

\footnotetext{
The costs of publication of this article were defrayed in part by the payment of page charges. The article must therefore be hereby marked "advertisement" in accordance with 18 U.S.C. Section 1734 solely to indicate this fact.
} 


\section{MATERIALS AND METHODS}

Study population. A group of 13 patients with moderate to severe airflow obstruction was studied (Table 1). All patients had COPD according to the American Thoracic Society (3) guidelines and chronic airflow limitation, defined as measured forced expiratory volume in $1 \mathrm{~s}\left(\mathrm{FEV}_{1}\right)<70 \%$ of reference $\mathrm{FEV}_{1}$. Furthermore, patients had irreversible obstructive airway disease $(<10 \%$ improvement of $\mathrm{FEV}_{1}$ predicted baseline after $\beta_{2}$-agonist inhalation). They were in clinically stable condition and not suffering from a respiratory tract infection or an exacerbation of their disease at least 4 wk before the study. Only one patient received supplemental oxygen. During rehabilitation, patients received maintenance (low-dose) respiratory medication that in general consisted of inhaled bronchodilators and inhaled corticosteroids. To confirm previously reported reduced baseline UCP3 levels in COPD, seven healthy age-matched control subjects were included (Table 1). Exclusion criteria were malignancy, cardiac failure, distal arteriopathy, recent surgery, severe endocrine, hepatic, or renal disorders, and use of anticoagulant medication. Written informed consent was obtained from all subjects, and the study was approved by the medical ethics committee of the University Hospital Maastricht (Maastricht, The Netherlands).

Intervention. All patients participated in an 8-wk standardized exercise training program consisting of a combination of endurance and strength exercise training. The daily program (5 days/wk) consisted of $2 \times 20$ min of submaximal cycle ergometry, $1 \times 20 \mathrm{~min}$ of treadmill exercise, $1 \times 30 \mathrm{~min}$ of gymnastics, and one session of unsupported arm exercise training (consisting of $10 \times 1$ min of exercise, each minute followed by $1 \mathrm{~min}$ of rest). A team of experienced physiotherapists tailored each individual training program on the patients' functional impairments in daily living and on the patients' muscular performance.

Body composition. Height was determined to the nearest $0.5 \mathrm{~cm}$ with subjects standing barefoot, and body weight was assessed to the nearest $0.1 \mathrm{~kg}$ while subjects wore light clothing and no shoes. In patients, fat-free mass (FFM) was estimated using single-frequency $(50 \mathrm{kHz})$ bioelectrical impedance analysis (Xitron Technologies, San Diego, CA) while subjects were in a supine position. FFM was calculated using the disease-specific equation (40). In healthy controls, FFM was determined by dual energy X-ray absorptiometry (Lunar, Madison, WI; see Ref. 9). Weight parameters were divided by squared height $\left(\mathrm{kg} / \mathrm{m}^{2}\right)$, resulting in the body mass index and FFM index, to adjust for body surface.

\section{Table 1. Subject characteristics}

\begin{tabular}{|c|c|c|}
\hline & COPD & Controls \\
\hline$N$ (male/female) & $13(6 / 7)$ & $7(4 / 3)$ \\
\hline Age, yr & 61 (SD 12) & 64 (SD 3) \\
\hline $\begin{array}{l}\text { Smokers/ex-smokers/never } \\
\text { smoked }\end{array}$ & $1 / 12 / 0$ & $1 / 4 / 2$ \\
\hline Height, m & 1.67 (SD 0.09) & $1.64(\mathrm{SD} 0.08)$ \\
\hline Weight, kg & $63(\mathrm{SD} 11)$ & 72 (SD 9) \\
\hline BMI, $\mathrm{kg} / \mathrm{m}^{2}$ & $22.7(\mathrm{SD} 1.1)$ & 26.7 (SD 4) \\
\hline FFM, kg & 44 (SD 6.9) & 49 (SD 8.2) \\
\hline FFMI, $\mathrm{kg} / \mathrm{m}^{2}$ & $15.9($ SD 2.2) & $18.0(\mathrm{SD} 2.3)^{*}$ \\
\hline $\mathrm{P}_{\mathrm{a}} \mathrm{O}_{2}, \mathrm{kPa}$ & 9.0 (SD 1.2) & \\
\hline $\mathrm{P}_{\mathrm{a}} \mathrm{CO}_{2}, \mathrm{kPa}$ & $5.4(\mathrm{SD} 0.7)$ & \\
\hline $\mathrm{FEV}_{1}, \%$ predicted & $37.1(\mathrm{SD} 11.8)$ & $119(\mathrm{SD} 22) \dagger$ \\
\hline DLCO, \% predicted & $47.0(\mathrm{SD} 23.5)$ & \\
\hline FVC, \%predicted & $75(\mathrm{SD} 11)$ & $123(\mathrm{SD} 21) \dagger$ \\
\hline
\end{tabular}

Values are means (SD). COPD, chronic obstructive pulmonary disease; BMI, body mass index; FFM, fat-free mass; FFMI, fat-free mass index; $\mathrm{P}_{a} \mathrm{O}_{2}$, arterial oxygen pressure; $\mathrm{P}_{\mathrm{a}} \mathrm{CO}_{2}$, arterial carbon dioxide pressure; $\mathrm{FEV}_{1}$, forced expiratory volume in $1 \mathrm{~s}$; DLCO, diffusion capacity for carbon monoxide; FVC, forced vital capacity. Significance of difference between groups: $* P<0.05$ and $\dagger P<0.001$.
Pulmonary function tests. Spirometry was used to determine, among others, the $\mathrm{FEV}_{1}$, with the highest value from at least three technically acceptable assessments being used. Diffusion capacity for carbon monoxide was measured by using the single-breath method (Masterlab; Jaeger, Wurzburg, Germany). All values obtained were expressed as a percentage of the predicted value (29). Arterial oxygen tension was determined (ABL 330; Radiometer, Copenhagen, Denmark) in a blood sample from the radial artery while breathing room air.

Exercise performance. An incremental bicycle ergometry test was performed on an electromagnetic braked ergometer (Corival 400; Lode, Groningen, The Netherlands) under supervision of a chest physician to investigate maximal leg exercise capacity. After a 2-min resting period and 1-min unloaded cycling, power was increased every minute by 10 watts. None of the subjects knew the exercise load, and all were encouraged to cycle at $60 \mathrm{rpm}$ until exhaustion. During the exercise test, heart rate, blood pressure, and transcutaneous oxygen saturation were monitored. Oxygen consumption $\left(\dot{\mathrm{V}}_{2}\right)$ and carbon dioxide production $\left(\mathrm{V}_{\mathrm{CO}_{2}}\right)$ were measured and calculated from breathby-breath analysis using a breathing mask (Oxycon Beta; Jaeger). Peak workload, $\dot{\mathrm{V}}_{2}, \dot{\mathrm{V}}_{\mathrm{CO}_{2}}$, and ventilation were used in the analysis.

Collection and processing of muscle tissue. After at least 3 days without training, postabsorptive muscle biopsies of the lateral part of the quadriceps femoris were obtained under local anesthesia by the needle biopsy technique (6). A part of the biopsy $( \pm 50 \mathrm{mg}$ ) was immediately frozen in liquid nitrogen and stored at $-80^{\circ} \mathrm{C}$ until further processing. From this, a $5 \%$ (wt/vol) homogenate was prepared by dispersion (Polytron PT 1600 E; Kinematica, Lucerne, Switzerland) followed by 1 min sonication (Branson 2210; Branson Ultrasonics) of the tissue in $250 \mathrm{mM}$ sucrose, $2 \mathrm{mM}$ EDTA, and 10 $\mathrm{mM}$ Tris (pH 7.4). Samples were centrifuged $\left(10 \mathrm{~min}, 10,000 \mathrm{~g}, 4^{\circ} \mathrm{C}\right)$, and the supernatant was used for the following enzyme activity assays: phosphofructokinase (PFK; EC 2.7.11; see Ref. 22), HAD (EC 1.1.1.35; see Ref. 5), CS (EC 2.3.3.1; see Ref. 38), and glycogen phosphorylase (GlyP; EC 2.4.1.1; see Ref. 37) were analyzed spectrophotometrically (Multiskan Spectrum; Thermo Labsystems, Breda, The Netherlands). The remaining pellet was resuspended in $3 \mathrm{vol}$ of ice-cold extraction buffer $\left(100 \mathrm{mM} \mathrm{Na} \mathrm{O}_{7} \mathrm{P}_{2} \cdot 10 \mathrm{H}_{2} \mathrm{O}, 5 \mathrm{mM}\right.$ EDTA, $1 \mathrm{mM}$ dithiothreitol, $\mathrm{pH} 8.5$ ), incubated on ice for $30 \mathrm{~min}$, and centrifuged ( $\left.10 \mathrm{~min}, 10,000 \mathrm{~g}, 4^{\circ} \mathrm{C}\right)$. From this, the supernatant was used for MyHC isoform analysis as described by Talmadge and Roy (41). Gels were run for $22 \mathrm{~h}$ using a Protean II xi Cell electrophoresis system (Bio-Rad, Veenendaal, The Netherlands) at $20 \mathrm{~mA}$ with increasing voltage to a maximum of 350 volts. About $1.0 \mu \mathrm{g}$ of protein was loaded per lane. Gels were silver-stained (Silver Stain Plus kit; Bio-Rad), scanned, and photographed with a scanning densitometer (Fluor-S MultiImager; Bio-Rad), after which bands were quantified using Quantity One software (Bio-Rad). I, IIA, and IIX $\mathrm{MyHC}$ isoforms were expressed proportionally to each other. The remaining part of the biopsy was placed in a drop of Tissue-tek (optimum cutting temperature compound) on a piece of cork and frozen in liquid nitrogen. From this, cryosections were collected and homogenized in ice-cold Tris-EDTA buffer at $\mathrm{pH}$ 7.4. UCP3 protein content and 4-hydroxy-2-nonenal (HNE)-protein adducts were determined as described previously $(4,13)$. In short, from each sample an equal amount of protein was loaded on a polyacrylamide gel, and Western blotting was performed using a rabbit polyclonal UCP3 antibody (code 1331; kindly provided by L. J. Slieker, Eli Lilly) or a rabbit polyclonal antibody against HNE-protein adducts (Calbiochem, San Diego, CA). Values were normalized using a standard sample to allow for intergel comparisons. For UCP3, however, it was not possible to use the same standard for the control vs. patient comparison and for the patients' before and after training comparison because of limited sample availability. Values were expressed as arbitrary units (AU).

Statistics. Data were analyzed using SPSS (Statistical Package for the Social Sciences, version 11.0 for Windows; SPSS, Chicago, IL). Differences between groups were analyzed with the Mann-Whitney 
$U$-test. Changes induced by the intervention were analyzed with the Student's $t$-test for paired data or, in case of subgroup analyses (with $n<10$ ), with the Wilcoxon signed-rank test for paired data. A two-tailed probability value of $<0.05$ was considered statistically significant. Data are presented as means (SD).

\section{RESULTS}

Subject characteristics are shown in Table 1. The results of training on the incremental cycle ergometry test in patients are presented in Table 2. After the $8 \mathrm{wk}$ of training, exercise capacity was improved. Both peak $\dot{\mathrm{V}}_{2}$ and the peak workload increased significantly (15 and $16 \%$, respectively; $P \leq 0.015$ ).

Muscular enzyme activities and MyHC isoform composition are presented in Table 3. The activities of the two enzymes involved in glycolytic metabolism (GlyP and PFK) were not different from baseline. In contrast, training induced an increase in oxidative capacity as reflected by the $30 \%$ elevated activity of CS.

Compared with the healthy controls, muscular UCP3 protein levels were reduced in COPD patients [41.4 (SD 17.3) vs. 20.7 (SD 17.8) AU, respectively], as shown in Fig. 1. In COPD, UCP3 protein level tended to increase after the training intervention [from 67.7 (SD 41.8) to 113.8 (SD 104.2) AU, $P=$ $0.062]$, as shown in Fig. $2, A$ and $B$. Figure $2 B$ clearly shows that the training-induced upregulation of UCP3 only occurred in a subset of the patients. HAD activity did improve in a subset of patients. HAD responders were defined as patients in which the HAD increased with $>15 \%$ (which is the mean increase for the whole group). The six HAD responders had an increase in HAD activity [from 48 (SD 26) to 70 (SD 44) U/mg protein, $P=0.028$ ], and the seven HAD nonresponders had no significant change in HAD activity [from 54 (SD 34) to 48 (SD 26) $\mathrm{U} / \mathrm{mg}$ protein]. Interestingly, despite the absence of a significant correlation $(r=-0.43 ; P=0.15)$ between the changed UCP3 levels and HAD activity, the training-induced change in UCP3 levels was more pronounced in HAD nonresponders than in HAD responders [87.0 (SD 82.9) vs. - 1.5 (SD 49.0) AU, $P=0.046]$, as shown in Fig. 2C. Moreover, in the HAD nonresponders, UCP3 protein levels increased significantly [from 80.9 (SD 52.6) to 167.9 (SD 109.1) AU, $P=$ $0.028]$, whereas training induced no significant increase in UCP3 levels in the HAD responders [from 52.2 (SD 18.6) to 50.7 (SD 54.0) AU, $P=0.753$ ]. There were no differences in baseline exercise capacity, body composition, or lung function between HAD responders and nonresponders. There was no association between baseline UCP3 levels and CS activities, nor between training-induced changes in UCP3 and CS.

Total levels of HNE-conjugated proteins were measured as an index of lipid peroxidation in pre- and posttraining biopsies

Table 2. Incremental cycle ergometry test

\begin{tabular}{|c|c|c|}
\hline & Baseline & After Training \\
\hline Peak load, watts & $55.7(\mathrm{SD} 27.5)$ & $67.1(\mathrm{SD} 32.8)^{*}$ \\
\hline Peak $\dot{\mathrm{V}}_{2}, \mathrm{ml} / \mathrm{min}$ & $902(\mathrm{SD} 327)$ & $1,045(\mathrm{SD} 316) *$ \\
\hline Peak $\mathrm{VCO}_{2}, \mathrm{ml} / \mathrm{min}$ & $896($ SD 485) & 997 (SD 373) \\
\hline Peak RQ & $0.96(\mathrm{SD} 0.16)$ & $0.94(\mathrm{SD} 0.12)$ \\
\hline Peak نंE, 1/min & $35.8(\mathrm{SD} 14.1)$ & $41.5(\mathrm{SD} 12.9)^{*}$ \\
\hline
\end{tabular}

Values are means (SD). $\mathrm{VO}_{2}$, oxygen consumption; $\mathrm{V}_{\mathrm{CO}_{2}}$, carbon dioxide production; RQ, respiratory quotient; $\dot{\mathrm{V}}$, ventilation. *Significant change $(P<0.05)$.
Table 3. Muscular changes after intervention

\begin{tabular}{lcc}
\hline \hline & Baseline & After Intervention \\
\hline MyHC I, \% & 24.5 (SD 7.2) & 22.2 (SD 5.8) \\
MyHC IIA, \% & 47.4 (SD 11.2) & 46.3 (SD 7.1) \\
MyHC IIX, \% & 28.1 (SD 10.3) & 31.5 (SD 8.7) \\
GlyP, U/mg protein & 185 (SD 107) & 192 (SD 117) \\
PFK, U/mg protein & 674 (SD 372) & 641 (SD 327) \\
CS, U/mg protein & 32 (SD 22) & 42 (SD 28)* \\
HAD, U/mg protein & 51 (SD 32) & 58 (SD 36) \\
\hline
\end{tabular}

Values are means (SD). MyHC, myosin heavy chain; GlyP, glycogen phosphorylase; PFK, phosphofructokinase; CS, citrate synthase; HAD, 3-hydroxyacyl-CoA dehydrogenase. * Significant change $(P<0.05)$.

from the COPD patients (a representative Western blot is shown in Fig. 3), but there was no significant change after training [from 0.50 (SD 0.20) to 0.45 (SD 0.15) AU]. There were no correlations between baseline UCP3 and HNE levels, nor between their training induced changes. Also, HNE levels were not different between HAD responders and nonresponders.

\section{DISCUSSION}

Limb muscles of patients with COPD are characterized by reduced levels of UCP3 compared with healthy controls. The main finding of the current study is that exercise training leads to an upregulation of UCP3 in COPD, which is exactly the opposite to what has been found in healthy subjects. Finally, we show that the UCP3 upregulation predominantly occurs in patients with no improvement in HAD activity. These observations are in line with the putative function of UCP3 as a protector against lipotoxicity.

As previously shown (13), we found that UCP3 levels were $\sim 50 \%$ lower in limb muscles of COPD patient compared with healthy age-matched controls. As mentioned earlier, the normal response to exercise training is an increase in oxidative

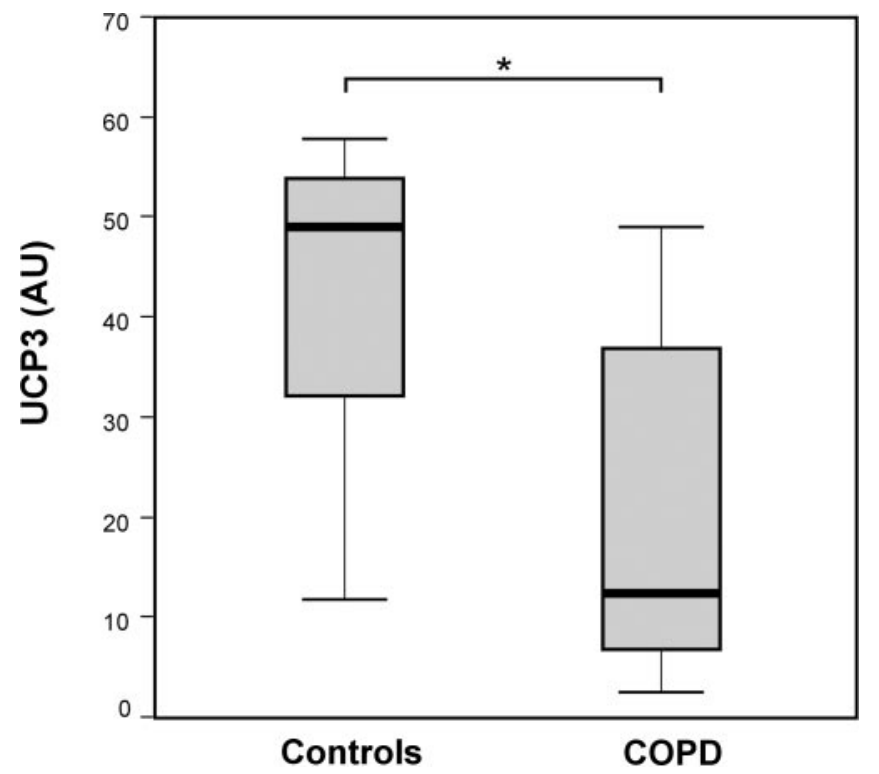

Fig. 1. Box plot showing the Western blot results for uncoupling protein-3 (UCP3) protein levels in chronic obstructive pulmonary disease (COPD) patients compared with controls. AU, arbitrary units. *Statistically significant difference. 
A
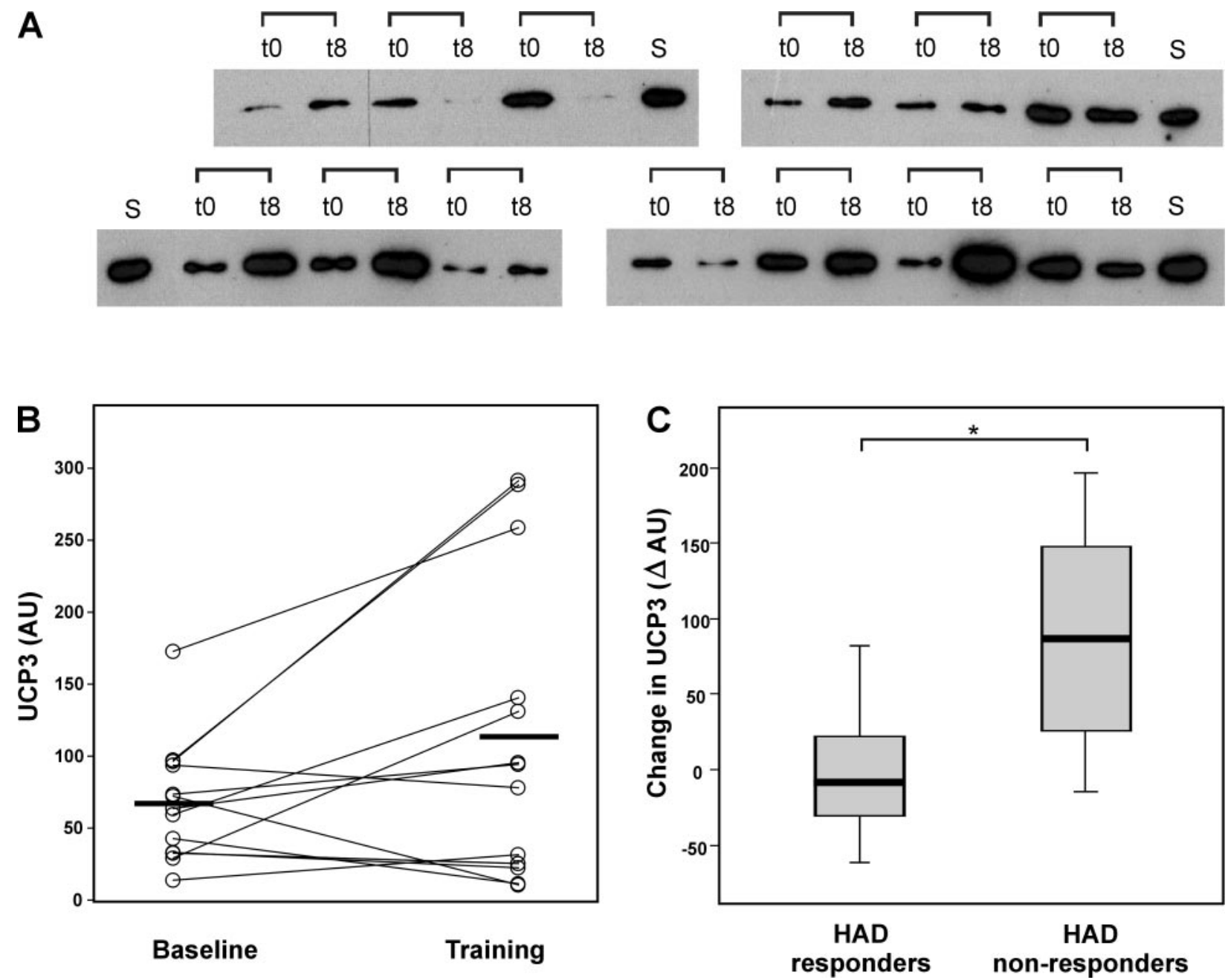

Fig. 2. A: Western blot results for UCP3 from all COPD patient muscle biopsies. Baseline and posttraining samples are labeled t0 and t8, respectively. On every gel, a standard sample was included (S) to correct for differences between gels/blots. B: individual pre- and posttraining UCP3 levels. Horizontal bars indicate means. $C$ : box plot showing the change in UCP3 level in 3-hydroxyacyl-CoA dehydrogenase (HAD) responders (subjects with $>15 \%$ increase in HAD activity after training) and HAD nonresponders. $\Delta$, change. $*$ Statistically significant difference.

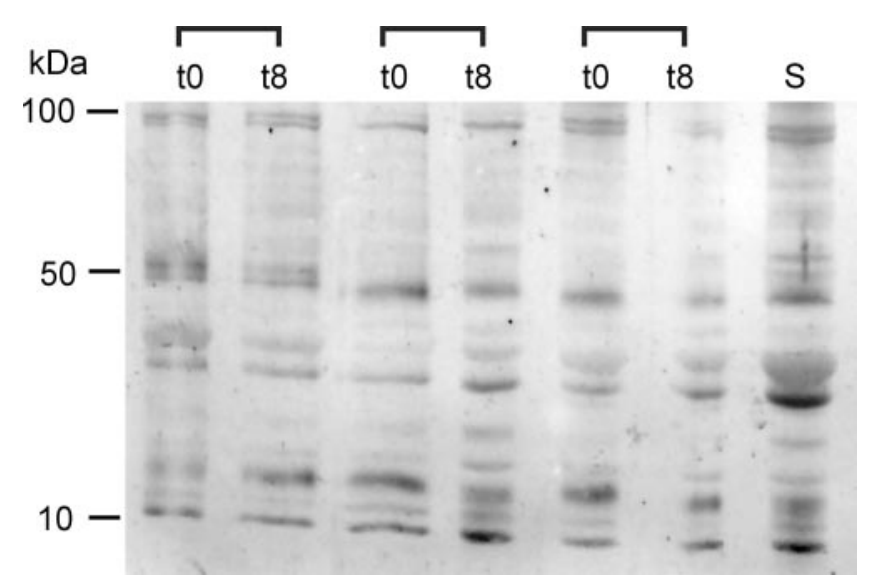

Fig. 3. A: representative Western blot results for 4-hydroxy-2-nonenal (HNE)protein adducts. Optical densities of bands ranging from $\sim 10$ to $\sim 100 \mathrm{kDa}$ were measured, and total HNE-protein adduct levels were calculated. On every gel, a standard sample was included to correct for differences between gels/blots. capacity and a downregulation of UCP3. For the whole group, we indeed found an improved oxidative capacity reflected by an improved CS activity. However, we did not find a further reduction of UCP3 after the 8-wk training intervention but a $\sim 1.7$-fold increase instead. Theoretically, the training-induced upregulation of UCP3 in COPD could be the result of changes in fiber-type composition and/or mitochondrial content. However, changes in UCP3 levels did not correlate with changes in oxidative capacity nor with $\mathrm{MyHC}$ isoforms. With respect to the fiber-type distribution, we found no training-induced changes in the relative composition of the MyHC isoforms I, IIA, or IIX, which is consistent with a previous study that described unaltered fiber-type proportions in COPD after a training intervention (42).

How can this opposite response of UCP3 to training in COPD be explained? There now is compelling evidence that UCP3 is not a key regulator of energy metabolism but that its main function is to protect mitochondria against lipotoxicity: It has been hypothesized that UCP3 serves as a transporter of fatty acid anions out of the mitochondrial matrix, thereby preventing accumulation of these anions, which would other- 
wise be prone to peroxidation by reactive oxygen species, which are also produced in the mitochondrial matrix, leading to lipid peroxidation and subsequently to mitochondrial damage (34). When the influx of fatty acids in the muscle cell exceeds the mitochondrial capacity to oxidize them, fatty acids will accumulate in the cytosol. Besides the active carnitine palmitoyl transferase-1 (CPT1)-dependent uptake of fatty acids in the mitochondria, passive fatty acid influx can also occur by a so-called flip-flop mechanism (15). However, fatty acids entering the mitochondrial matrix via the latter route cannot be oxidized (because they lack a coenzyme A group) but will be deprotonated and become fatty acid anions. These are unable to flip-flop back over the mitochondrial membrane and need a transporter to be exported. UCP3 has been shown to be able to transport fatty acid anions (39), and, in conditions when the fatty acid availability exceeds the oxidative capacity, UCP3 is indeed upregulated (33). In addition, acutely blocking CPT1, which enhances the influx of fatty acids by the flip-flop mechanism, upregulates UCP3 (35). Again, the normal response to training is improved activities of enzymes involved in oxidative metabolism, including that of $\operatorname{HAD}(10)$, a marker of fat oxidative capacity. Consistent with the above-mentioned function for UCP3, the patients with unimproved HAD activities, referred to as HAD nonresponders, showed a marked (2-fold) increase in UCP3 response, whereas UCP3 did not change in the HAD responders. In other words, the capacity to oxidize fatty acids apparently increased sufficiently in some of the patients, whereas in the other one-half this was not the case and UCP3 needed to be upregulated. Although the definition of HAD responders and nonresponders (more or less improvement compared with the group average) may be somewhat arbitrary, these are interesting observations that deserve more attention in future research.

In line with the above-mentioned mechanism, failure of the "HAD-UCP3 system" would lead to accumulation of fatty acid anions in the inner mitochondrial membrane and/or mitochondrial matrix and would be prone to lipid peroxidation. Indeed, mice lacking UCP3 were shown to have increased levels of muscular oxidative damage and lipid peroxidation (7). In the current study, we measured levels of HNE-conjugated proteins as an index of lipid peroxidation. However, we found no training-induced differences in the patient group. Also, we found no clear association of HNE levels with UCP3 levels or HAD activities. It can be speculated that enhanced lipid peroxidation might be prevented by a sufficient increase of either $\mathrm{UCP} 3$ or HAD. On the other hand, it must be stated that the muscle biopsies were obtained at rest and not after acute exercise, a situation in which oxidative stress and lipid peroxidation are much more prominent. It is therefore possible that differences in HNE levels would have been found after acute exercise.

The training-induced upregulation of UCP3 suggests that UCP3 levels are restored roughly to normal levels. The question then remains as to why UCP3 levels are reduced in COPD patients. This study does not provide the evidence for this; therefore, we can only speculate. UCP3 is, at least at the mRNA level, upregulated by circulating fatty acid levels (21). Decreased plasma free fatty acid levels have indeed been reported in COPD (18). The effect of fatty acids on UCP3 expression probably involves the peroxisome proliferator-activated receptors (PPARs), since the promoter of UCP3 has been shown to contain a PPAR-responsive element (1). It could be speculated that PPAR activity is reduced in COPD, although at present the PPARs have not been studied in COPD for that purpose. Interestingly, PPARs may be downregulated by hypoxia (27). In addition, Zhou et al. (43) showed that acute hypoxia upregulated UCP3 but that prolonged exposure to hypoxia led to a reduction of UCP3 in rat muscle. It is therefore tempting to hypothesize that chronic hypoxia is involved in reduced UCP3 levels in COPD. Although we did not evaluate daily activity patterns in this study, it can be assumed that COPD patients are less physically active than healthy elderly individuals and that muscle disuse is also involved in reduced UCP3 levels. This is, however, unlikely because the effect of inactivity has been studied previously in tetraplegic subjects, a condition characterized by profound muscle disuse, and UCP3 was found to be upregulated in this model (17). Hence, more research is required to determine which factors are indeed involved in the low UCP3 contents in COPD and what the underlying molecular mechanisms are.

In summary, UCP3 levels are reduced in untrained sedentary patients suffering from COPD. This can be restored by an exercise training intervention, which has been shown to improve oxidative capacity as well. The fact that the upregulation of UCP3 in response to training does not occur in patients with a sufficient increase in HAD activity is entirely in line with the accumulating evidence that the physiological function of UCP3 is to protect the mitochondria against lipotoxicity. More research is required to establish if reduced UCP3 levels in COPD reflect a pathophysiological state and whether UCP3 is a potential target for therapeutic intervention.

\section{GRANTS}

The research of H. R. Gosker was supported by European Union Grant QLK6-CT-2002-02285. The research of P. Schrauwen has been made possible by fellowships of the Royal Netherlands Academy of Arts and Sciences. M. K. C. Hesselink holds a VIDI grant for innovative research from the Netherlands Organization for Scientific Research (Grant No. 016.066.359). This study was also supported by a research grant from GlaxoSmithKline.

\section{REFERENCES}

1. Acin A, Rodriguez M, Rique H, Canet E, Boutin JA, and Galizzi JP. Cloning and characterization of the $5^{\prime}$ flanking region of the human uncoupling protein 3 (UCP3) gene. Biochem Biophys Res Commun 258: $278-283,1999$.

2. Allaire J, Maltais F, LeBlanc P, Simard PM, Whittom F, Doyon JF, Simard C, and Jobin J. Lipofuscin accumulation in the vastus lateralis muscle in patients with chronic obstructive pulmonary disease. Muscle Nerve 25: 383-389, 2002.

3. American Thoracic Society. Standards for the diagnosis and care of patients with chronic obstructive pulmonary disease. Am J Respir Crit Care Med 152: S77-S121, 1995.

4. Barreiro E, Gea J, Corominas JM, and Hussain SN. Nitric oxide synthases and protein oxidation in the quadriceps femoris of patients with chronic obstructive pulmonary disease. Am J Respir Cell Mol Biol 29: 771-778, 2003.

5. Bergmeyer HU, Gawehn K, and Grassl M. 3-Hydroxyacyl-CoA dehydrogenase. In: Methods of Enzymatic Analysis, edited by Bergmeyer HU. Weinheim, Germany: Verlag Chemie, 1974, p. 474.

6. Bergstrom L. Muscle electrolytes in man. Determination by neutron activation analysis on needle biopsy specimens A study on normal subjects, kidney patients, and patients with chronic diarrhea. Scand J Clin Lab Invest 68: 1-110, 1962.

7. Brand MD, Pamplona R, Portero-Otin M, Requena JR, Roebuck SJ, Buckingham JA, Clapham JC, and Cadenas S. Oxidative damage and phospholipid fatty acyl composition in skeletal muscle mitochondria from mice underexpressing or overexpressing uncoupling protein 3. Biochem $J$ 368: 597-603, 2002. 
8. Couillard A, Maltais F, Saey D, Debigare R, Michaud A, Koechlin C, LeBlanc P, and Prefaut C. Exercise-induced quadriceps oxidative stress and peripheral muscle dysfunction in patients with chronic obstructive pulmonary disease. Am J Respir Crit Care Med 167: 1664-1669, 2003.

9. Engelen MPKJ, Schols AMWJ, Heidendal GAK, and Wouters EFM. Dual-energy X-ray absorptiometry in the clinical evaluation of body composition and bone mineral density in patients with chronic obstructive pulmonary disease. Am J Clin Nutr 68: 1298-1303, 1998.

10. Essén-Gustavsson B and Henriksson J. Enzyme levels in pools of microdissected human muscle fibres of identified type. Adaptive response to exercise. Acta Physiol Scand 120: 505-515, 1984.

11. Franssen FME, Wouters EFM, Baarends EM, Akkermans MA, and Schols AMWJ. Arm mechanical efficiency and arm exercise capacity are relatively preserved in COPD. Med Sci Sports Exerc 34: 1570-1576, 2002.

12. Gosker HR, Lencer NHMK, Franssen FME, Wouters EFM, van der Vusse GJ, and Schols AMWJ. Striking similarities in systemic factors contributing to decreased exercise capacity in patients with severe chronic heart failure or COPD. Chest 123: 1416-1424, 2003.

13. Gosker HR, Schrauwen P, Hesselink MKC, Schaart G, van der Vusse GJ, Wouters EFM, and Schols AMWJ. Uncoupling protein-3 content is decreased in peripheral skeletal muscle of patients with COPD. Eur Respir J 22: 88-93, 2003.

14. Gosker HR, van Mameren H, van Dijk PJ, Engelen MPKJ, van der Vusse GJ, Wouters EFM, and Schols AMWJ. Skeletal muscle fibre type shifting and metabolic profile in patients with COPD. Eur Respir J 19: 617-626, 2002.

15. Hamilton JA and Kamp F. How are free fatty acids transported in membranes? Is it by proteins or by free diffusion through the lipids? Diabetes 48: 2255-2269, 1999.

16. Hesselink MK, Keizer HA, Borghouts LB, Schaart G, Kornips CF, Slieker LJ, Sloop KW, Saris WH, and Schrauwen P. Protein expression of UCP3 differs between human type 1, type $2 \mathrm{a}$, and type $2 \mathrm{~b}$ fibers. FASEB J 15: 1071-1073, 2001

17. Hjeltnes N, Fernstrom M, Zierath JR, and Krook A. Regulation of UCP2 and UCP3 by muscle disuse and physical activity in tetraplegic subjects. Diabetologia 42: 826-830, 1999.

18. Jakobsson EJ and Jorfeldt L. Blood fuel metabolites at rest and during exercise in patients with advanced chronic obstructive pulmonary disease with and without chronic respiratory failure. Respiration 57: 304-309, 1990.

19. Jakobsson P, Jorfeldt L, and Brundin A. Skeletal muscle metabolites and fibre types in patients with advanced chronic obstructive pulmonary disease (COPD), with and without chronic respiratory failure. Eur Respir J 3: 192-196, 1990.

20. Jakobsson P, Jorfeldt L, and Henriksson J. Metabolic enzyme activity in the quadriceps femoris muscle in patients with severe chronic obstructive pulmonary disease. Am J Respir Crit Care Med 151: 374-377, 1995.

21. Khalfallah Y, Fages S, Laville M, Langin D, and Vidal H. Regulation of uncoupling protein-2 and uncoupling protein-3 mRNA expression during lipid infusion in human skeletal muscle and subcutaneous adipose tissue. Diabetes 49: 25-31, 2000.

22. Ling KH, Pastkau V, Marcus F, and Lardy HA. Phosphofructokinase. Skeletal muscle I. Methods Enzymol 9: 425-429, 1966.

23. Mador MJ, Deniz O, Aggarwal A, and Kufel TJ. Quadriceps fatigability after single muscle exercise in patients with chronic obstructive pulmonary disease. Am J Respir Crit Care Med 168: 102-108, 2003.

24. Maltais F, LeBlanc P, Simard C, Jobin J, Berube C, Bruneau J, Carrier L, and Belleau R. Skeletal muscle adaptation to endurance training in patients with chronic obstructive pulmonary disease. Am J Respir Crit Care Med 154: 442-447, 1996.

25. Maltais F, Simard AA, Simard C, Jobin J, Desgagnes P, and LeBlanc P. Oxidative capacity of the skeletal muscle and lactic acid kinetics during exercise in normal subjects and in patients with COPD. Am J Respir Crit Care Med 153: 288-293, 1996.

26. Maltais F, Sullivan MJ, LeBlanc P, Duscha BD, Schachat FH, Simard C, Blank JM, and Jobin J. Altered expression of myosin heavy chain in the vastus lateralis muscle in patients with COPD. Eur Respir $J$ 13: $850-854,1999$.

27. Narravula $\mathbf{S}$ and Colgan SP. Hypoxia-inducible factor 1-mediated inhibition of peroxisome proliferator-activated receptor alpha expression during hypoxia. J Immunol 166: 7543-7548, 2001.

28. Puente-Maestu L, Tena T, Trascasa C, Perez-Parra J, Godoy R, Garcia MJ, and Stringer WW. Training improves muscle oxidative capacity and oxygenation recovery kinetics in patients with chronic obstructive pulmonary disease. Eur J Appl Physiol 88: 580-587, 2003.

29. Quanjer P, Tammeling GJ, Cotes JE, Pedersen OF, Peslin R, and Yernault JC. Standardized lung function testing. Eur Respir J 6: 5-40, 1993.

30. Russell AP, Somm E, Debigare R, Hartley O, Richard D, Gastaldi G, Melotti A, Michaud A, Giacobino JP, Muzzin P, LeBlanc P, and Maltais F. COPD results in a reduction in UCP3 long mRNA and UCP3 protein content in types I and IIa skeletal muscle fibers. J Cardiopulm Rehabil 24: 332-339, 2004.

31. Russell AP, Somm E, Praz M, Crettenand A, Hartley O, Melotti A, Giacobino JP, Muzzin P, Gobelet C, and Deriaz O. UCP3 protein regulation in human skeletal muscle fibre types I, IIa and IIx is dependent on exercise intensity. J Physiol 550: 855-861, 2003.

32. Schrauwen $\mathbf{P}$ and Hesselink M. UCP2 and UCP3 in muscle controlling body metabolism. J Exp Biol 205: 2275-2285, 2002.

33. Schrauwen $\mathbf{P}$ and Hesselink M. Uncoupling protein 3 and physical activity: the role of uncoupling protein 3 in energy metabolism revisited. Proc Nutr Soc 62: 635-643, 2003.

34. Schrauwen $\mathbf{P}$ and Hesselink MK. The role of uncoupling protein 3 in fatty acid metabolism: protection against lipotoxicity? Proc Nutr Soc 63: 287-292, 2004.

35. Schrauwen P, Hinderling V, Hesselink MK, Schaart G, Kornips E, Saris WH, Westerterp-Plantenga M, and Langhans W. Etomoxirinduced increase in UCP3 supports a role of uncoupling protein 3 as a mitochondrial fatty acid anion exporter. FASEB $J$ 16: 1688-1690, 2002.

36. Schrauwen P, Hoeks J, Schaart G, Kornips E, Binas B, Van De Vusse GJ, Van Bilsen M, Luiken JJ, Coort SL, Glatz JF, Saris WH, and Hesselink MK. Uncoupling protein 3 as a mitochondrial fatty acid anion exporter. FASEB J 17: 2272-2274, 2003.

37. Schreiber WE and Bowling S. An automated assay of glycogen phosphorylase in the direction of phosphorolysis. Ann Clin Biochem 27: 129-132, 1990.

38. Shephard D and Garland PB. Citrate synthase from rat liver. Methods Enzymol 13: 11-16, 1969

39. Skulachev VP. Anion carriers in fatty acid-mediated physiological uncoupling. J Bioenerg Biomembr 31: 431-445, 1999.

40. Steiner MC, Barton RL, Singh SJ, and Morgan MD. Bedside methods versus dual energy X-ray absorptiometry for body composition measurement in COPD. Eur Respir J 19: 626-631, 2002.

41. Talmadge RJ and Roy RR. Electrophoretic separation of rat skeletal muscle myosin heavy-chain isoforms. J Appl Physiol 75: 2337-2340, 1993.

42. Whittom F, Jobin J, Simard PM, Leblanc P, Simard C, Bernard S, Belleau R, and Maltais F. Histochemical and morphological characteristics of the vastus lateralis muscle in patients with chronic obstructive pulmonary disease. Med Sci Sports Exerc 30: 1467-1474, 1998.

43. Zhou M, Lin BZ, Coughlin S, Vallega G, and Pilch PF. UCP-3 expression in skeletal muscle: effects of exercise, hypoxia, and AMPactivated protein kinase. Am J Physiol Endocrinol Metab 279: E622E629, 2000. 